\title{
Op welke wyse word die waarheid gelieg? Die kortverhale van T.T. Cloete
}

\author{
Heilna du Plooy \\ Departement Afrikaans en Nederlands \\ Potchefstroomse Universiteit vir $\mathrm{CHO}$ \\ POTCHEFSTROOM
}

\begin{abstract}
Truthful lying in T.T. Cloete's short stories

In this article an attempt is made to characterize the short stories of T.T. Cloete in Die waarheid gelieg. The theory of focalization is examined briefly and a definition of focalization which emphasizes the epistemological aspects of perspective and formulation is used to examine the stories. The stories are compared to stories of Kafka and Borges indicating the resemblances, especially the fascination with the unexpected and weird contradictions in reality, as well as the differences. An intratextual reading of the stories and poems by the same author is undertaken in an attempt to formulate the epistemic position of the focalization in the texts. The article concludes that the Christian worldview as well as a poetics of nomenliterature of the abstract author can be deduced from the stories on account of the assumption that epistemic stances are reflected in the narrative representation and can be communicated to readers by means of propositional attitudes.
\end{abstract}

\section{Inleiding}

Die waarheid gelieg van T.T. Cloete verskyn in 1984. Cloete het in hierdie stadium reeds bekendheid verwerf as digter (met Angelliera, 1980 en Jukstaposisie, 1982) en omdat hy ook as literator bekend is, het die bundel verhale heelwat belangstelling uitgelok. Tog was die reaksie van resensente nie deurgaans gunstig nie. Die verhale het verder baie minder aandag gekry as Cloete se poësie in studies en literêre navorsing. En tot nou toe (middel 1995) het Cloete ook nog nie weer enige prosawerk gepubliseer nie. 
In hierdie artikel wil ek opnuut na die verhale in Die waarheid gelieg gaan kyk, veral uitgaande van die vraag: Met watter soort literatuur het 'n mens hier te make?

\section{Die aanvanklike resepsie van die verhale}

In die aanvanklike resensies is Die waarheid gelieg hoofsaaklik evaluerend beskou, soos wat dit gebruiklik is in ons literêre praktyk. Die opvallendste eienskappe van die verhale is beskryf en die lesersreaksies is aangetoon.

Die verhale is aanvanklik beskryf in terme van veral die intertekstuele verwysings waaruit heelparty van die verhale groei en hierdie intertekstuele verbande kan inderdaad met groot vrug verder ontgin word (vgl. veral Aucamp, 1984). Verder is daar aandag gegee aan die bewuste vakmanskap, die besigwees met die woord as leuen wat wel tot die waarheid kan lei, die bemoeienis met die literatuur in die literatuur self (Brink, 1984; Johl, 1984; Van der Walt, 1984; Smuts, 1984; Ester, 1984). Die grootste deel van die besprekings is egter afgestaan aan tematiese kwessies rondom die verhouding waarheid en leuen, wat deur die titel vooropgestel word en in die verhale deurwerk (Brink, 1984; Smuts, 1984; Johl, 1984; Ester, 1984; Aucamp, 1984; Prinsloo, 1984a; Prinsloo, 1984b).

Tegniese kwessies is aangesny, soms positief, maar ook negatief. Daar is gevoel dat die verhale te anekdoties en dus nie werklik opwindend is nie (Brink, 1984; Johl, 1984), dat daar soms te veel eksplikasie voorkom (Smuts 1984; Brink, 1984) en dat daar 'n te duidelike aansluiting by 'n ouer styl, veral dié van Van Melle, is (Brink, 1984). Van der Walt (1984) verwys egter na die manier waarop vertel word deur die verhale te beskryf as die resultaat van 'n sintese van belewing en literatuurkennis en wel op so 'n wyse dat die verhale bewys lewer van "selfverowerde gebied, verworwe wins" wat daaraan 'n eie stempel gee. Venter (1984) lê klem op die verrassende wending, die kontrastering van realistiese en nugter vertelling met die irrasionele verhaalinhoud sodat die verhale handel oor "die mens se uitgelewerdheid aan die lewe".

Ek wil in hierdie artikel die resensies as vertrekpunt gebruik en nie daamee in dispuut tree nie. Vanselfsprekend bevat die verhale hoogtepunte en is daar ook tekortkominge, verhaalmatig en stilisties. Maar watter literatuur is volmaak? En wie sal sê hoe die volmakte literatuur moet lyk? Ons weet almal dat die literatuur ' $n$ verkleurmannetjie is, en dat die literêre kritiek op sy beste steeds aan die heersende literêre mode en die ideologiese klimaat uitgelewer is (en ook móét wees om effektief te wees!). Verder speel die persoonlike aanvoeling en 
smaak van die kritikus ook 'n bepalende rol sodat die evaluering van die literatuur baie selde sonder kontroversie is.

In hierdie artikel gaan dit vir my glad nie daarom of die aanvanklike resepsie van die verhale, evaluerend gesproke, korrek of foutief is nie, maar om die feit dat baie min van die resensente gepoog het (Van der Walt, 1984 en Venter, 1984 miskien die uitsonderings) om rekenskap te gee van die soort literatuur waarmee 'n mens hier te make het. Wat my interesseer, is dan juis om te probeer uitvind met 'watter soort literatuur' die leser hier gekonfronteer staan.

Die vertellinge is moeilik te omskryf, al is hulle oënskynlik eenvoudig, soms inderdaad anekdoties. Die verhale is nie enkellynig nie, maar die band met ander literêre tekste, die 'gesprek' met ander skrywers se werk, is myns insiens ook nie voldoende antwoord op die kwessie van aard nie, hoewel dit interessante interpretasies kan oplewer.

\section{3. 'n Poging tot omskrywing}

\subsection{Visie en fokalisasie}

In Cloete se verhale word daar meestal van buite na gebeure gekyk. In verhale soos "Dokter Diedericks leer om te lag", "Die ramp" en "Die gaping" word die gebeure onbetrokke weergegee, byna in die vorm van 'n soort verslag. Die aanvangsinne van die verhale stel meestal dadelik die 'objektiewe' toon vas:

Dit is in die nasomer aan die einde van Maart.

Dokter Diedericks is 'n geneesheer.

("Dokter Diedericks leer om te lag", 67)

Sy het uit 'n gesin van mooi dogters gekom. 'n Arm gesin wat met tabak en kleinvee geboer het op 'n rivierplaas, aan die noordelike oewer.

("Die gaping", 86)

Selfs wanneer daar 'n ek-verteller optree, kry 'n mens 'n soort saaklikheid wat afstand bevestig. Daar kom baie min emosioneel gelade woorde voor, al is dit 'n verslag van 'n belewenis van die verteller self:

Ons was in Houtbaai met vakansie. Daar het my vrou baie siek geword. Al geneesheer in die omgewing was 'n afgetrede dokter wat net goed was om haar hand vas te hou, soos my vrou gesê het.

("Die ramp", 83)

Hierdie vertelstyl is opvallend in die bundel as geheel en in die sterkste verhale lewer die verteller baie min kommentaar op die verhaalverloop. Waar daar wel 
kommentaar voorkom, is dit in 'n soort opsommende en samevattende styl, ook vanaf ' $n$ afstand.

In "Die bedrieër" word die aanval op die Homan soos volg verklaar:

Hy het hulle verontrus - vir niks.

Hy het hulle drome onherbergsaam gemaak.

Hy het 'n sprokie kom vertel en ten slotte gesê dat dit net 'n sprokie is (14).

Inderwaarheid sou die weglating van die kommentaar in hierdie verhaal nie veel aan die verhaal verander nie, omdat dit wat die kommentaar sê reeds in die beskrywing van die gebeure geïmpliseer is. Met of sonder kommentaar behou die verhale egter deurgaans 'n soort afstandelikheid, asof die waarnemer (fokalisator) en die verteller nie ná aan die verhaal staan nie, en as die verteller of fokalisator ' $n$ karakter in die verhaal is, is dit nogtans asof die emosionele betrokkenheid by die vertel van die verhaal in bedwang gehou word of doelbewus onderbeklemtoon word.

'n Mens kan dus sê dat die verhale hoofsaaklik vertel word vanuit 'n eksterne vertellersposisie en ook vanuit eksterne fokalisasie. So 'n meganiese beskrywing van verteller en fokalisator sê egter min of niks van die aard van die verhouding tussen vertelde inhoud en die vertelhandeling nie en dra daarom nie by tot 'n poging tot interpretasie van die verhale nie. So 'n narratologiese beskrywing volgens die geykte kategorieë bevredig dus nie en maak ' $n$ geringe bydrae tot die omskrywing en verklaring van die soort verhale waarmee 'n mens hier te make het.

Dit lyk dus vir my asof 'n mens die visie waaruit die verhale geskryf is, van nader sou moes bekyk. Onder visie wil ek hier sowel fokalisasie as vertelling insluit omdat 'n mens hier met 'n omvattender en meer komplekse verhouding tussen vertelde inhoud, die fokus daarop en die vertelling daarvan te make het.

Mieke Bal (1980:108 e.v.) defmieer fokalisasie as die verhouding tussen die waarnemer en dit wat waargeneem word. Wanneer 'n mens egter gaan kyk na Genette (1980: 160 e.v.) se oorspronklike verduideliking van die term, blyk dat hy die term fokalisasie gebruik as onderdeel van die kategorie van narratiewe modaliteit. Net soos wat die vorm van 'n werkwoord die verhouding tussen die subjek en die handeling wat in die werkwoord beskryf word, kan aandui, speel modaliteit in die verhalende teks 'n bepalende rol. Dit gaan dan hoofsaaklik om die aard van die verhouding tussen die vertelde (histoire) en die vertelhandeling. Genette sluit onder narratiewe modaliteit in sowel die afstand tussen vertelinstansie en vertelde inhoud (wat mimeties of diëgeties kan wees) as perspektief. Perspektief verdeel hy egter weer in twee onderafdelings, 
naamlik fokalisasie, die oriënterende perspektief wat die verhaal bepaal, en voice wat as die "narrating situation" omskryf word.

As 'n mens egter die verhale in Die waarheid gelieg binne hierdie teoretiese raamwerk beskryf ten opsigte van fokalisasie en jy sou daarmee volstaan dat die fokalisasie ekstern is wat die afstand betref, is daar nog niks gesê van die soort 'oog' of ingesteldheid waarmee gekyk word nie. Die opvallendste eienskappe van die verhale bly sodoende onverklaar en een van hierdie eienskappe is juis die 'doelbewuste' afstandehikheid in die vertelling, iets wat byna as 'n intellektuele dissipline of ' $n$ berekende verwydering beskryf kan word. Verder is daar ten spyte van die objektiwiteit waarmee groot gedeeltes van die verhale vertel word, 'n paradoks tussen die stelligheid van die vertelstyl en die afloop van die verhale wat hierdie stelligheid juis ondermyn. Daar is tekens nie net van 'n vervreemding as verteltegniek nie (soos deur die Russiese Formaliste as kunsgreep verduidelik), maar ook van 'n 'vervreemding' tussen verteller en dit wat hy vertel asof die verteller self met bevreemde oë kyk en moet kyk na wat hy sien.

In "Die klein gevaar" word die jong man na sy terugkeer van militêre diens soos volg beskryf:

Hy het teruggekeer met die dik blou aar onder sy oog dikker en blouer as ooit. Hy was bruin gebrand en sigbaar gesond. Sy opgewondenheid was groot, sigbaar aan daardie aar (91).

$\mathrm{Na}$ talle angsdrome wat oënskynlik onnodig is (met die onderliggende suggestie dat 'n mens deur jou angs juis die onheil op jou kan rig), word die jong vroutjie wakker:

Die drome oorweldig haar. Beangs tas sy in die donker na Daniel. Hy is roerloos en koud. Hy lê soos die salmvis op sy sy, die oog groot en rond oop, nie bleek nie maar eienaardig blosend (94).

Die ou vrou in "Die gaping" sterf 'n vuurdood omring van water:

Alles brand toe sy wakker word. Sy is te verskrik om te roep en gil, sy is te swak om te beweeg. Die vuur is om haar en knetter soos 'n waterval. Dit reen nou op ander plekke, hoër op oor die rivier. Die waterval raas, soos 'n vuur wat knetter. Dat water soos vuur kan raas (89).

Die suggestie dat die gebreekte bril die ongeluk van die weldoener veroorsaak het (in "Die ramp"), stel die verteller voor 'n absoluut vreemde verantwoordelikheid: 
Maar die huid rondom sy oë is bleek, soos van iemand met swak oë wat 'n bril dra met baie dik lense wat min lig deurlaat op die gesig rondom die oe (85).

\subsection{Verhale van die 'bevreemdende' wending}

In die sterkste verhale in Die waarheid gelieg is daar 'n moeilik omskryfbare verhouding tussen die vertelinstansie, die fokalisator en die vertelde inhoud. Dit is dan ook die verhale waarin byna geen kommentaar gelewer word nie en waarin die blote gebeure iets unheimisch suggereer, wat 'n mens die langste bybly. Die oënskynlike onbetrokkenheid en saaklikheid van die waamemende en vertellende instansie is myns insiens 'n kunsgreep, 'n vorm van understatement waardeur die vreemdheid van die onverwagse wending vooropgestel word en verder versterk word deur die 'bevreemde' oë waardeur gekyk word.

Hierdie verhale herinner aan verhale van Kafka waarin die karakters deur 'n soort absurde logika, soos in 'n nagmerrie, aan onbekende en dikwels vyandige magte oorgelewer word (Kafka, 1949; Flores, 1983). Die karakters in Kafka se werk is blykbaar nie in staat om hulle te oriënteer in die wêreld waarin hulle leef nie. Die wêreld is 'n soort labirint "waarin het vanselfsprekende en het verbluffende, het alledaagse en het raadselachtige, het logische en het tegenstrijdige met elkaar verstrengeld zijn" (Kerkhoff, 1967:325). 'n Verdere kenmerkende eienskap van Kafka se verhale is dat "de details raak en scherp beschreven zijn, maar het verband waarin deze hun funksie hebben, blijft duister" (Kerkhof, 1967:325).

Hierdie uitsprake kan aan enige van Kafka se bekende verhale geillustreer word. In "The Judgement" word die vader wat oud, afgeleef en hulpbehoewend is, op verrassende wyse 'n veroordelende en gerigsprekende magsfiguur en die seun, wat hom oor die vader wou ontferm, word die slagoffer. Die verhouding tussen vader en seun, die verhouding tussen skuld en onskuld, die verhouding tussen kennis en verborgenheid, tussen openlikheid en selfbedrog, tussen uitgelewerde en uitleweraar verskuif voortdurend sodat die aannames waarmee die verhaal begin deurlopend gekompliseer en ondernyn word.

Op soortgelyke wyse skryf Jorge Luis Borges 'vreemde' verhale, verhale waarin steeds daama gestreef word om iets te ontdek, om insig te verkry, maar die insig bly ontwykend. Vir Borges gaan dit nie om idees as sodanig nie, maar om "their resonances and suggestions, the drama of their possibilities and impossibilities, the immobile and lasting quintessence of ideas as it is distilled at the dead centre of their warring contradictions" (Irby, 1971:16). Omdat die mens nooit die wêreld waarin hy moet bestaan, kan begryp nie, het hy behoefte 
daaraan om 'n koherente samehangende en logiese wêreld te maak, te konstrueer, soos blyk uit die verhaal "Tlön, Uqbar, Orbis Tertius". Dié verhaal handel oor die ontdekking in 'n ensiklopedie van 'n beskrywing van 'n 'ander' wêreld. Wanneer die ensiklopedie met die verstommende inskrywing van 'n (vermoedelik) nie-bestaande wêreld later weer gesoek word, is dit onverkrygbaar en onopspeurbaar. Die uiteindelike suggestie is dat die wêreld wat beskryf is, in der waarheid nie ' $n$ inskrywing in die ensiklopedie was nie, maar die werklikheid. Die mens se hebbelikheid tot en afhanklikheid van gekonstrueerde werklikhede word so aan die orde gestel (Borges, 1971:52):

Ten years ago any symmetry with a semblance of order - dialectical materialism, anti-Semitism, Nazism - was sufficient to charm the minds of men. How could one do other than submit to Tlön, to the minute and vast evidence of an orderly planet? It is useless to answer that reality is also orderly. Perhaps it is, but in accordance with divine laws - I translate: inhuman laws - which we never quite grasp. Tlö is surely a labyrinth, but it is a labyrinth devised by men, a labyrinth destined to be deciphered by men.

Interessant genoeg verduidelik Borges hier ook in die verhaal self die kerngedagte van sy vertelling, dat die mens naamlik verskillende ideologiese en psigologiese raamwerke tot stand bring om die werklikheid te probeer hanteer. Hierdie raamwerke word die matriks waardeur na die wêreld gekyk word, want die werklikheid self, sonder die verklarende raamwerke, is totaal onbegryplik. Daarom is die raamwerke en die wêreld soos dit daardeur lyk, so aantreklik.

Die saaklike styl, die gestrooptheid, die onopgesmuktheid byna tot die eentonige toe van sowel Borges as Kafka se werk, is algemeen bekend. Gemeet aan die maatstawwe van die kontemporêre populêre skryf, van 'n meevoerende vloei, 'n strelende bekende wending, sou Kafka en Borges swak vaar. Maar wat hulle werk so boeiend maak, is die visie van waaruit gekyk word: die visie wat bepaal watter kwessie aan die orde gestel word, die visie wat die problematiese in 'n skynbaar gewone situasie raaksien, wat die verhaal wil vertel op 'n manier dat hierdie visie ook aan die leser oorgedra word.

Borges gebruik 'n ironiese blik om aan sy skeptisisme estetiese vorm te gee, terwyl Kafka se verhale te kenne gee dat die mens eintlik niks bet om aan vas te hou nie, dat sy lewe geen regverdiging het nie. Omdat die mens onherroepelik kontak met alle metafisies magte verloor het, beskik hy volgens Kafka oor geen maatstaf om essensiële van nie-essensiële dinge te onderskei nie (Kerkhof, 1967:325).

In verskeie van Cloete se verhale vind ek iets terug van dieselfde verwondering, 'n byna grillige verwondering oor die wêreld wat 'n mens by Kafka en Borges 
aantref. Hierdie verwondering word uitvoerig in die laaste afdeling van die artikel bespreek. Die bepalende verskil tussen dié verhale en Cloete se werk word ook uitvoeriger bespreek, maar die ooreenkomste kan nie misgekyk word nie. Dit is asof skrywers soos hierdie (en daar is nog baie ander wat ek hier nie noem nie) die impuls tot skryf put uit 'n bepaalde manier van kyk na die werklikheid, met ander woorde uit die visie op die verhaalgegewe. Die verhaal word vertel op 'n manier wat nie net die gebeure of gegewe oordra nie, maar wat ' $n$ bepaalde betekenis impliseer of suggereer, ' $n$ betekenis (Sinn) wat daarop dui dat betekenis juis nie geredelik aan die verhaal toegedig kan word nie; dat die gebeure so belangrik is, juis omdat dit onverklaarbaar is.

\section{3 'n Ander fokus op fokalisasie}

Die standaardomskrywings van fokalisasie soos hierbo gegee, verskaf nie 'n adekwate raamwerk om die aard van 'n bepaalde soort kyk of waarneming te omskryf nie. Rimmon-Kenan (1983:77 e.v.) voel die noodsaak aan van 'n meer gekompliseerde omskrywing van die verhouding tussen die fokalisator en die verhaalgegewe. Sy probeer die skopus van die term fokalisasie uitbrei deur te stel dat fokalisasie nie net ' $n$ visuele begrip is nie. Sy toon dan aan dat daar verskillende fasette van fokalisasie onderskei kan word, naamlik 'n perseptuele, psigologiese en ideologiese faset, wat telkens die moontlikhede van ' $n$ interne of eksterne fokalisasie bepaal. Daar is egter teoretici wat selfs met hierdie uitbreiding nog nie tevrede is met die moontlikhede van die konsep nie.

In 'n resente artikel oor fokalisasie, waarin hy sekere hipotetiese vorme van fokalisasie ondersoek, sluit David Herman (1994:230 e.v.) aan by Genette deur klem te plaas op modaliteit as die bepalende faktor in fokalisasie. Die strak sistematiese kategorieë van fokalisasie word gekritiseer as ontoereikend omdat fokalisasie veel meer omvat as 'n eksterne of interne posisie selfs al sou perseptuele, psigologiese en ideologiese fasette 'n rol speel.

Herman (1994:231) omskryf fokalisasie soos volg:

Ways of focalizing a story can thus be redescribed as the narrative representation of propositional attitudes, i.e. modes of focalization encode into narrative form various kinds of epistemic stances that can be adopted towards what is being represented in a narrative.

Die kategorisering in 'blokke' van verskillende soorte fokalisasie word vervang met 'n glyskaal van mountlikhede: “... we can interpret types of focalization as scalar phenomena, ranked incrementally along a continuum of epistemic modalities" (Herman, 1994:231). Herman (1994) betoog in hierdie artikel dat fokalisasie ' $n$ belangrike aanduiding is van die intensionele betekenis (Sinn) 
van taal teenoor die referensiële betekenis (Bedeutung) van taal en dat kennis van die semantiek in grammatika en linguistiek 'n mens hierin moet help. Fokalisasie word beïnloed en bepaal deur die epistemologiese posisie van waarneming en die proposisies wat in die formulering van die waarneming gebruik word, dra die epistemiese implikasies van die vertelling aan die leser oor.

Met so 'n siening kan 'n mens veel meer skakeringe in fokalisasie onderskei en omskryf, aangesien die manier van kyk na die wêreld (die werklike wêreld en fiksionele wêrelde - moontlike wêrelde, fantastiese of absurde wêrelde) op grond van die episteem waarbinne gedink en geleef word, 'n oneindige aantal variasies kan aanneem (vgl. Ryan, 1992:528-553).

In Cloete se verhale gaan dit eksplisiet nie om referensie nie, maar om sin (intensionele en dus multi-interpretabele betekenis) - daarvan is die titel van die bundel reeds ' $n$ duidelike aanwyser. Die geskrif is ' $n$ leuen, maar die leuen hou verband met die waarheid, want die werklikheid het 'n misterieuse en onbekende kant, 'n kant wat hom nie laat ken nie en wat nie te kenne gee wat 'waar' sou wees nie. En hier toon Cloete se verhale 'n raakpunt sowel as 'n verskil met Kafka en Borges: al drie skrywers word gefassineer deur die absurde, die ongewone, die grillige selfs, al drie kyk ironiserend en sardonies na buitengewone en gewone dinge en al drie vermoed iets vreemds, iets geheimsinnigs, selfs iets demonies in die gewoonste dinge.

In "Die Evangelie volgens Markus" (Borges, 1981:42-47) is Espinosa eintlik 'n vrydenker en hy lees aan die Gutres die Evangelie volgens Markus voor eerder uit verveling as iets anders terwyl hulle deur die vloedwater vasgekeer is. Uiteindelik word Espinosa deur die Gutres as 'n soort verlossende Christusfiguur beskou en bou hulle vir hom 'n kruis: hy moet vir hulle die verlossing waarvan hy gelees het, waar maak.

Dieselfde grillige verloop van 'n aanvanklike skadelose bedoeling kom ook voor in Die waarheid gelieg. In "Kommunikasie" word die siek man se goeie bedoelings omgekeer. Hy gee vir die dogtertjie wat koerante in die hospitaal kom verkoop meer geld omdat hy haar bewonder vir haar deursettingsvermoë, maar die kind sien die ekstra geld as 'n aanklag teen haarself, gooi dit weg en kom nie weer terug nie. In "Veg om te verloor" verloor die wenners (die ryk familie) veel meer as die verloorders en hulle moet eers verloor (in die twee dogters se simboliese teruggee-handeling) om uiteindelik te kan wen. In hierdie verhale (soos ook in "Die brandstigters" en "Mooi klere") is die omkering van verwagtinge tog nog relatief skadeloos en die ironiserende verwisseling van voorspoed en teëspoed ligweg spottend aangebied. 
Sommige verhale oorskry egter die grens van blote kuriositeit en stel eksistensiële krisisse direk aan die orde. "Die boere-pietà" suggereer 'n onverklaarbare verband tussen twee beelde van Santa: in elke geval sit sy met 'n kind op haar skoot. Daar is in Santa se tienerjare die insident met die spuls klein seuntjie op haar skoot:

Een aand het ek in die huislike geselskap op haar skoot aan die slaap geraak - soos dit dikwels die geval was - en gedroom ek beleef haar met my hele liggaam. Dit was 'n droom wat geweet het wat ek ongedroom nie kon geweet het nie ... Dit moet 'n groot verleentheid vir die huislike geselskap gewees het, want ek is ru wakker gemaak ... (47).

Jare later sit dieselfde meisie, nou 'n "groot growwe vrou" wat nooit glimlag nie, soos 'n standbeeld met die progeriekind op haar skoot: "Die aand toe ons terugry, dink ek, wat 'n vreemde gesig; 'n boere-pietá" (54).

Die tweede toneel is ' $n$ byna gruwelike gestalte (wangestalte) van Maria met haar Seun. Die verhaal gee geen antwoord anders as om die ironie en kontras tussen die twee insidente daar te stel en 'n moontlike vreemde verband te suggereer nie. Die verband tussen die twee tonele in Santa se lewe kan toevallig wees, die tweede toneel kan 'n byna onheilige vergelding insinueer, terwyl die medelye met die lyding van die vrou ook in die benaming "boerepietà" gesuggereer word. Daar is dus geen voor die hand liggende verklaring vir die saak nie, maar daar sit iets gruweliks in die waarneming en aanbieding daarvan wat sou kon suggereer: daar is sulke onverklaarbare gruwelikhede en dit moet gelééf word, dit moet verduur word deur diegene wat dit beleef en diegene wat dit opmerk.

In hierdie verhaal, soos ook in "Die biegvader" en "Wie weet?" neem gebeure 'n onverwagte en vreemde verloop, asof daar net onder die oppervlak ander en ongekende en onvoorspelbare magte aan die werk is. Die karakters ken hulleself nie altyd nie en daar is 'n suggestie van 'n onvermydelike tweeledigheid in mense, 'n soort onderliggende Janusgestalte ("Die biegvader", "Geloofgenesing", "Die vraag antwoordlieg"). Dit is asof die onvolkomenheid, die skewe, selfs die demoniese in mense deur geringe aanleiding geopenbaar kan word (ook "Die bedrieër").

\section{Die epistemiese implikasies van Cloete se visie}

Is dit moontlik om sinvolle opmerkings te maak oor die epistemiese posisie van waaruit Cloete as skrywer kyk? Die probleem met so 'n onderneming is dat 'n mens hier beweeg op die prekêre terrein tussen teks, implisiete outeur (die ordenende hand in die teks), abstrakte outeur (die skrywerspersoonlikheid soos 
uit sy werk afgelei) en werklike outeur met 'n bepaalde lewens- en wêreldbeskouing.

Desnieteenstaande moet daar tog 'n poging aangewend word om dit te doen, want in Cloete se werk is daar eggo's van verskillende soorte. Daar is 'n literêre sofistikasie wat verwysingsveld sowel as tegniek betref, daar is 'n tydgenootlike filosofiese aanvoeling soos blyk uit die besef van die relatiwiteit van dinge, maar dit is duidelik nie al nie. Ek vind in Cloete se verhale, ten spyte van die ooreenkomste met onder meer Kafka en Borges, 'n ander klemplasing, 'n ander fokus wat myns insiens te make het met die visie van waaruit gekyk en geskryf is (en ek probeer my hier in hoofsaak by die skrywerspersoonlikheid, die abstrakte outeur, bepaal, hoewel ander aspekte noodwendig 'n bykomende rol speel).

Die absolute relativisme van Borges en Kafka vind ek nie by Cloete nie. Wel 'n verwondering oor die onverklaarbare, 'n bewustheid daarvan dat die divine laws waarvan Borges praat, die wêreld 'n vreemde plek maak, 'n plek met 'n grimmige kant wat onverwags na vore kan tree. Die verligting van die jong getroudes in "Die klein gevaar" as die man na drie maande veilig van die grens af huis toe kom, word herhaaldelik beklemtoon en bevestig. Die jong vrou besef telkens dat haar nagmerries drome is en verlig dink sy dan elke keer dat sy haar nie verder hoef te bekommer nie. Sy slaap rustig verder en in werklikheid is haar man reeds dood. Die deurlopende verwysings na die kloppende aar onder die jong man se regteroog word terugskouend 'n onheilspellende vooruitwysing na sy dood met "die oog groot en rond oop, nie bleek nie maar eienaardig blosend" (94).

In "Die ramp" staan grimmigheid voorop: die goeie man wat die verteller help, breek sy bril en maak self ' $n$ ongeluk. Die beskrywing van die man se weerlose oë, wit omraam deur die bleek vel wat deur sy bril teen die son beskerm is, suggereer die man se totale weerloosheid waar hy dood lê. Daar is die implikasie van 'n ongemaklike wete, selfs 'n aanklag teen die verteller, onlogies skuldig in sy onskuld.

In "Die gaping" staan die onlogiese weer eens in die slot van die verhaal prominent. Waarom sterf hierdie vrou, wat haar lewe lank met die geluid van die waterval in haar ore gelewe het, in vuur? Waarom moet sy so 'n dood sterf as sy tog ' $n$ goeie mens was, glad nie eers opstandig oor haar lot om ' $n$ invalide te word nie? Waarom moes die kat, wat haar geselskap en aanspraak was, die brand veroorsaak (en self eintlik ongeskonde daarvan afkom)? Hierdie verhaal bevat iets skrynends wat, juis as gevolg van die gestroopte onderbeklemtoning, sterker uitstaan. 
Om 'n greep te kry op die invalshoek van die skrywersblik, het ek intratekstueel gaan lees, dit wil sê ek het die verhale in verband gebring met ander Cloetetekste en spesifiek met gedigte wat duidelike raakpunte met die verhale vertoon. Toegegee, volgens my lesings en, ook toegegee, slegs 'n beperkte analise van enkele tekste, maar ek glo dat die resultaat deur wyer ondersoek bevestig sal word. Dit is opvallend hoe voor die hand liggend verbande tussen die verhale in Die waarheid gelieg en gedigte in die bundel Allotroop is. Die rede lê waarskynlik daarin dat die twee werke kort na mekaar verskyn het, dus in dieselfde periode ontstaan of verwerk is (Die waarheid gelieg in 1984 en Allotroop in 1985).

Ek beperk my uitsprake oor die epistemiese posisie van die skrywer in hierdie tekste tot hoofsaaklik twee waarnemings, een wat lewensbeskoulik van aard is en die ander poëtikaal. Hiermee is ' $n$ mens terug by die siening van Herman (1994) wat stel dat die fokalisasie en visie in 'n teks beïnvloed en bepaal word deur die epistemologiese posisie van waarneming en dat die proposisies wat in die formulering van die waarneming gebruik word, die epistemiese implikasies van die vertelling aan die leser oordra.

\subsection{Die lewensbeskoulike visie}

Voorafgegaan deur die waarneming dat die verhale meestal oor etiese kwessies gaan of met die grense van lewe en dood te make het, wil dit voorkom asof daar in die meeste verhale telkens een of ander mitiese kwessie aan die orde gestel word (die term mities hier in wye verband gebruik soos in Jolles se Einfache Formen - 1956). Die skrywer beskryf die oppervlak (van gebeure en sake), maar dis duidelik dat die implisiete doel van die beskrywing ' $n$ vraag na die metafisiese betekenis daarvan is.

Die verhaal "Die gaping" het as subtitel of as motto 'n aanhaling uit Pascal: "Il y a une opposition invincible entre Dieu et nous". Die verhaal word dus gelees teen die agtergrond van die uitspraak dat daar 'n onoorbrugbare, onontkombare, onoorwinlike afstand of kontras of opposisie tussen God en die mens is. Daar is dus 'n 'gaping' tussen God en mens, wat kan dui op die onverklaarbaarheid van die voorbeskikking van God vir die mens: die mens kan nie en sal nooit begryp waarom dinge op 'n bepaalde manier verloop nie. As ' $n$ mens nou in ag neem dat Pascal, skrywer, natuur- en wiskundige, filosoof en as Christen-moralis apologeet vir die Christelike geloof uit die 17de eeu, sy lewe lank geworstel het met die eeue-oue vraag na die verband tussen geloof en wetenskap, dan word daar nog ' $n$ intertekstuele verband geaktiveer wat met die epistemologiese aannames agter die verhaal te make het. Die verwysing na Pascal plaas die verhaal in die lyn van vele debatte rondom die stryd tussen 
geloof en wetenskap, maak dit deel van die botsing tussen intellek en menslike logika, wat wil maar nie altyd kan begryp nie, en geloof wat weet dat begrip ondergeskik is aan die wete van goddelike beskikking (vgl. Aerts e.a., 1967:393-395). Wat egter duidelik is in "Die gaping" en ook in die meeste ander verhale is dat die skrywer-denker bly wonder oor die vreemdheid van die verskynsels in die lewe, dat geloof nie die behoefte aan navraag beëindig of stil nie en dat dit imperatief is om juis die onverstaanbare te verwoord.

"Die gaping" kan ook saamgelees word met twee lykdigte in Allotroop, naamlik "1 in memoriam m." (75) en "2 in memoriam lenie" (101). Waarskynlik gaan hierdie twee gedigte oor dieselfde persoon, Magdalena (as aangeneem word dat M. sowel as Lenie vir Magdalena staan). In " 2 in memoriam lenie" word vuur en water eksplisiet genoem en die gedig het 'n verwysing na Jesaja 43 as subtitel.

In Jesaja 43 word die volk van die Here verseker van sy bystand, selfs in vuur en in water:

Wees nie bevrees nie, want Ek het jou verlos; jy is myne!

As jy deur die water gaan, is ek by jou; en deur die riviere - hulle sal jou nie oorstroom nie; as jy deur vuur gaan, sal jy jou nie skroei nie, en die vlam sal jou nie brand nie.

Want Ek is die Here, jou God, die Heilige van Israel, jou Heiland ...

Omdat jy kostelik is in my oë, hooggeag is, en Ek jou liefhet ...

Wees nie bevrees nie, want $\mathrm{Ek}$ is met jou ...

(Aanhaling uit 1933-Bybelvertaling.)

Die gedig " 2 in memoriam lenie" eindig so:

dié wat ek met liefde bederf

moet deur water en deur vuur sterf

die water sal nie oor jou vloei nie

en die vuur kán jy verduur

In "Die gaping" sterf die ou vrou wat haar lewe lank langs die water gewoon het, in vuur. In die metaforiek van die verhaal word die vuur en water noodwendige teeppole van mekaar, skuif lewe en dood, water en vuur, beweging en passiwiteit oor mekaar, word die vuur en die waterval in terme van mekaar beskryf, wanneer die ou vrou (bewegingsgestrem as verlamde) in die vuur sterf:

Vandat sy dit kon onthou, het daardie waterval geraas. Lewe is beweging.

Die waterval lewe, en die rivier vloei uit oertye hier verby, tot in ewigheid.

Tot in die oneindige (86).

Die vuur is om haar en knetter soos 'n waterval (89). 
Die verband met Jesaja 43 lyk dus aangewese en via dié verwysing kan 'n verband tussen die metaforiek en die tema in die verhaal en die lykdigte in Allotroop gesien word.

"Die nut van die krommes" berus ook op 'n opposisie. Die siek man is so bly dat hy goeie nuus ontvang het by die dokter, en hy loop en bid 'n dankbare gebed:

In die strate het hy geloop en bid, soos sy vader vroeër in die voetpaadjies van sy plaas. Hy het gevra dat dat Hy hom moet help om nooit weer in een of ander vorm ondankbaar te wees nie, solank hy leef en so gesond is soos vanoggend (37).

Dan besef hy die kinders op die skoolterrein lag vir hom, vir sy vreemde manier van beweeg. Hy sien dit as 'n toets vir sy geloof: "onmiddellik weet hy dat Hy hom gehoor het, ingegryp het in en onder sy gebed, deur skoolseuns se spotlag te gebruik, om hom te toets ..." (38). Maar hy dink tog, selfvertroostend, dat God die krommes ook gebruik: "Kyk na die werk van God: wie kan reguit maak wat Hy krom gemaak het?" (38).

Dié gedagte word ook reeds voonuitwysend aangedui deur die subtitel van die verhaal, "They also serve ...". Hierdie aanhaling kom uit Sonnet (on his Blindness) van John Milton, die blinde Engelse digter waarin hy vra: "Doth God exact day-labour, light deny'd?" In die sestet van die sonnet word die vraag soos volg beantwoord:

'God doth not need

Either man's work or his own gifts. Who best

Bear his mild yoke, they serve him best. His state

Is kingly: thousands at his bidding speed

And post o'er land and ocean without rest;

They also serve who only stand and wait.'

In die verhaal word die man se gedagtes uitvoerig weergegee en daar word eksplisiet gesê dat hy die kinders se spot sien as 'n toets om sy dankbaarheid waar te maak, om dus in sy geloof en dankbaarheid die pyn van die bespotting te oorskry. Die spot word dus 'n geloofstoets.

Die oënskynlik sukkelende gang van die man wat 'n bepaalde soort nutteloosheid aandui, staan sodoende in skerp kontras tot die feit dat hy weet en glo dat hy God selfs in sy gestremdheid ook dien. Die man se dankbaarheid vir die klein mate van gesondheid wat hy het, staan ook in teenstelling tot die kinders se vanselfsprekende aanvaarding van hulle gesondheid en krag en jeug 
en dus hulle nuttigheid, wat hulle die vrypas gee om te lag vir 'n ander se oënskynlike nutteloosheid.

Dié verhaal is opgedra aan "Herman" en toon sodoende 'n verband met die lykdig in Allotroop met die titel "in memoriam herman". In die gedig word 'n lykstoet beskryf bestaande uit 6 mense, " 3 seuns 2 meisies en die ma" en Josef die kreupel Tswana. In hierdie twee tekste is daar 'n bykomende dimensie omdat 'n mens outobiografiese kodes in albei kan onderskei. Op grond van die bemoeienis met siekte, op grond van die feit dat die hoofkarakter so moeilik en selfs opvallend potsierlik loop, kan die verhaal in verband gebring word met die skrywer self. Dieselfde geld vir die gedig, want Cloete het inderdaad drie seuns, twee dogters en 'n kreupel Tswana tuinier. Die Herman in die verhaal en die gedig dui dus op die skrywer in ' $n$ verskuilde maar wel herkenbare gedaante en "in memoriam herman" is dan 'n lykdig wat die digter vooruitskouend vir homself geskryf het.

Daar is ook heelparty ander gedigte wat handel oor die digter se gestremdheid. Die mees eksplisiete gedig is "artropatie" (Allotroop, 50) waarin nie net die digter se pyn en lyding uitgebeeld word nie maar ook sy identifikasie met Christus. Dit gaan veral daarom dat die gestremde mens steeds die objek van God se bemoeienis is, dat hy deur God geteister word en nogtans tot sy eer lewe:

hy krul my kraakbeen

en karnuffel my kruppel

hy skroei my ingewande met ' $n$ gloed

met dorings deur my knie en voetkussing en skeen

laat hy my voor hom stram huppel

met dorings deur my palms handeviervoet

"Die nut van die krommes" en "in memoriam Herman" kan dus albei met Cloete self in verband gebring word, nie net vanweë die siektebeskrywing nie, maar ook vanweë die karakters in die gedig wat op sy gesin dui. 'n Mens kan in die verhaal van die gestremde en siek man en die 'bypassende' gedigte die outobiografiese kodes aandui. Maar die religieuse ondertoon in albei tekste is duidelik, net soos wat die verwysing na Jesaja 43 en die verband tussen dood en vuur en water met die verhaal "Die gaping" in verband gebring kan word. Hierdie aanduidings kan dus in alle redelikheid met die verhalebundel in geheel in verband gebring word.

Hierdie aanduidings gee duidelike blyke van die visie waaruit die verhale geskryf is. Cloete se verwondering oor die wêreld en sy beskrywing daarvan kom nie uit 'n relativistiese lewens- en wêreldbeskouing nie. Dit gaan hier om 
die vrae van 'n gelowige Christen. Die vrae word gevra met verwondering oor die onverstaanbaarheid, die gebrek aan (menslike) logika, die gruwelikheid, die grilligheid van dit wat in die lewens van mense voorkom, maar die belangrike is dat die vrae gevra word. Geloof maak dit immers nie duidelik waarom dinge lyk soos hulle lyk en waarom die lewe verloop soos dit verloop nie, en die gelowige mens staan steeds verwonderd voor die vrae.

Die verhale staan almal in die teken van 'n groot waarom. Daar is aan die lewe die gewone, die kenbare, begryplike en voorspelbare kant, maar op die gewoonste tye en plekke, wat ons as volkome voorspelbaar beskou, kom daar 'n knak en dan is alles skielik vreemd. En natuurlik verwonder die skrywer, ook as gelowige mens, hom daaroor. Miskien is juis die volgehoue vraagstelling die eerlikste geloofsbelydenis.

\section{2 'n Poëtikale denkstruktuur}

Hoe kan die manier beskryf word waarop daar gekyk word na die vertelde inhoud in hierdie verhale? Hieroor kan sekerlik, soos oor die meeste dinge wat interpretasie verg, nie finale antwoorde gegee word nie. 'n Mens kan egter wel voorlopige opmerkings maak oor die poëtikale posisie van waaruit die skryfondememing aangepak word, oor die epistemologiese raamwerk wat die keuse van proposisies rig.

Wat baie duidelik is, is dat hier, net soos in Cloete se poësie, op volgehoue wyse konkrete dinge beskryf word, ook dat dinge konkreet gemaak word deur dit te beskryf. Juis in die gewoonheid van sake of situasies, is die verrassende moontlikhede: die potensiële vreemdheid en vervreemding sit ingebed in die alledaagse. Die gruwelike en die gewone voer 'n intieme saambestaan. Die noukeurige beskrywings van juis dit wat pynlik is, word die instrument waardeur insig verkry word:

Die kind lei aan progerie. Hy is nou agtien jaar, 'n klein geplooide, verrimpelde, seniele mannetjie. Sy sit daar met haar knieë ver uitmekaar. Hy lê daar op haar skoot met sy skrefiesoë, in 'n dom slaap; sy kop hang skeef in die hoek van haar regterelmboog, sy linkerarm om haar nek, die ander een slap langs haar onderbeen. Sy bene hang aan die linkerkant van haar skoot af (54).

Dan dink die verteller aan haar as 'n "boere-pietá", en in die woord word sowel die ironiese bedremmeldheid, die verskrikking en verslaenheid, as die verhewenheid, as 'n soort potensiële heiligheid van die vrou se omstandighede vasgevang. Wat uit die benoeming spreek, is begrip vir die dilemma sowel as vir die vreemde diskrepansies daarin, onteenseglik ook 'n diepe deernis met die 
vrou. Op dieselfde wyse word pynlike herinneringe aan die vader besweer in "Die vriendelike gode" en 'n hartseer droom oor almal wat reeds dood is in "Nugter".

Die stories wat leuens is, is ook die waarheid omdat soortgelyke dinge in die werklikheid te vinde is. Die skrywer wil op 'n manier met die gruwelike en grimmige in interaksie tree, in gesprek tree, hy wil dit juis aanspreek deur dit te beskryf, dit selfs dalk op dié wyse besweer. Die weerlose oë van die dooie man met die stukkende bril, die rooi salmoog van die jong man moet beskryf word sodat dit onder die aandag gebring word. Die vreemde dood van die (oënskynlike) trooster, biegmoeder en teisteraar van die verlamde vrou in "Wie weet?" moet vrae vra nie net oor die onmenslikheid van superregverdiges nie, maar ook oor die sin van die verstommende fases van 'n talmende dood.

Die aandag aan alledaagse detail in die verhale en ook die onpretensieuse anekdotiese styl lyk dus vir my deel te wees van hierdie beswerende funksie van skryf. Die benoeming van die mees gewone en die vreeslike langs mekaar, op dieselfde trant, met dieselfde afstandelike 'objektiwiteit', is 'n poging om die demoniese dinge net soos die gewone, juis omdat hulle saam daar is, aan die orde te stel; om daarop ' $n$ greep te probeer kry, nie noodwendig om dit te beheer nie, maar om te kenne te gee dat dit bekend is, dat dit raakgesien word.

In die saaklike neerskryf van die 'konkrete' van geliegde gevalle sit 'n aanvoeling vir die mistiek agter dinge - want niks is immers wat dit op die oppervlak skyn te wees nie. Al weet 'n mens nie altyd wat iets is of waarom dit is nie, is dit belangrik om te weet en te kenne te gee dat jy weet dit is. Die verhale kan dus, net soos Cloete se poësie, beskryf word as nomenliteratuur, literatuur van die benoeming van die saak self wat 'n aanvoeling vir die mistieke betekenis van die bestaan van dinge impliseer:

Maar die nomen is die konkretisering van die konkretisering. Dit is die plek waar die buitengewoonheid aan die orde moet kom, waar 'n uitsig op die misterie gebied moet word (Terblanche, 1993:235).

Agter die skynbaar onemosionele beskrywing sit daar dus eksistensiële en mitiese vrae en 'n duidelike poëtikale opset. Of lesers almal dink dat hierdie proses suksesvol in die verhale uitgevoer is, is vir my hier irrelevant: ek dink dit is belangriker om te probeer uitvind wat gebeur, epistemologies en poëtikaal gesproke, in die verhale.

\section{Slot}

In die 'leuenagtige' beskrywing van potensiële waar gevalle, tree die skrywer konkreet in interaksie met die wêreld vanuit sy bepaalde hoek van visie. Wat 
hy daar sien en wat hy in die verhale weergee, is die epiphany, die intuitiewe en skielike insig van 'n verborge betekenis van 'n saak of gebeurtenis (vgl. Shaw, 1972:139). So 'n moment van openbaring, daardie belewenis van die moontlikheid van 'n betekenis of sin groter en wyer as dit waarmee ons denkraamwerke ons toerus, die momentele begrip dat iets bestaan wat groter en dieper is as wat jy selfs sou kon verwag, dit is waarna die skrywer soek. Vir Cloete is hierdie bewussyn, soos dit vir my lyk, ook 'n bewussyn van God se onverklaarbare beskikking vir die wêreld. Die manier van skryf, die skryfhandeling self het dan ook as oogmerk die oordra van hierdie spesifieke siening van sake sodat die leser ook die epiphany kan ervaar in die leeshandeling van hierdie tekste.

Die skrywer wat aanvoel dat mistieke magte die werklikheid vorm en omvorm en verwring, die skrywer met 'n visioenêre aanvoeling, skryf om hierdie aanvoeling en visie met sy lesers te deel - hoe moeilik of hoe grimmig sy taak ook al is.

\section{Bibliografie}

Aerts, J., Bachrach, A.G.H., Stuiveling, G., Mussche, Achilles \& Wessels, P.B. (reds.) 1967. Moderne Encyclopedie der Wereldliteratuur. Gent : Wetenschappelijke Uitgeverij.

Aucamp, Hennie. 1984. T.T. Cloete op sy beste 'n verteller van formaat. Die Vaderland, 2 Julie.

Bal, Mieke. 1985. De theorie van vertellen en verhalen. Muiderberg : Coutinho.

Borges, Jorge Luis. 1981. Die vorm van die swaard en ander verhale. Uit Spaans vertaal deur Sheila Cussons. Kaapstad : Tafelberg.

Borges, Jorge Luis. 1971. Labyrinths - Selected Stories and Other Writings. (Edited by Donald A. Yates and James E. Irby.) Harmondsworth : Penguin Books.

Brink, André P. 1984. Cloete se waarheid hier soms skeef gelieg. Rapport, 29 Julie.

Cloete, T.T. 1985. Allotroop. Tafelberg: Kaapstad.

Cloete, T.T. 1984. Die waarheid gelieg. Kaapstad: Tafelberg.

Cuddon, J.A. 1979. A Dictionary of Literary Terms. London: Andre Deutsch. Ester, H. 1984. Het bewuste virtuositeit van T.T. Cloete. Zuid-Afrika, 61(11/12).

Flores, Angel (ed.) 1983. Explain to Me Some Stories of Kafka. New York : Gordian Press.

Genette. G. 1980. Narrative Discourse: An Essay in Method. Translated by Jane E. Lewin. Ithaca : Cornell University Press. 
Herman, David. 1994. Hypothetical Focalization. Narrative, 2(3):230-253, Oct.

Irby, E. 1971. Introduction. In: Borges, Jorge Luis. Labyrinths - Selected Stories and Other Writings. (Edited by Donald A. Yates and James E. Irby.) Harmondsworth : Penguin Books. p. 15-23.

Johl, Ronél. 1984. T.T. Cloete maak sy prosadebuut. Beeld, 8 Oktober. Jolles, André. 1956. Einfache Formen. Halle : Max Niemeyer Verlag. Kafka, Franz. 1949. In the Penal Settlement - Tales and Short Prose Works.

(Translated from the German by Ernst Kaiser and Eithne Wilkins.) London : Secker \& Warburg.

Kerkhof, E.L. 1967. Kafka, Franz. In: Aerts, J., Bachrach, A.G.H., Stuiveling, G., Mussche, Achilles \& Wessels, P.B. (reds.) Moderne Encyclopedie der Wereldliteratuur. Gent : Wetenschappelijke Uitgeverij. p. 323-328.

Prinsloo, Koos. 1984a. Kortkuns as geskenk op 60. Beeld, 31 Mei.

Prinsloo, Koos. 1984b. Cloete verras weer met prosa. Oosterlig, 4 Junie. Rimmon-Kenan, Shlomith. 1983. Narrative Fiction-Contemporary Poetics. New York : Methuen.

Ryan, Marie-Laure. 1992. Possible Worlds in Recent Literary Theory. In Style, 26(4):528-553, Winter.

Shaw, Harry. 1972. Dictionary of Literary Terms. New York : McGraw-Hill. Smuts, J.P. 1984. Oor waarheid en leuen. Die Burger, 28 Junie.

Terblanche, J.E. 1993. Nomemliteratuur. Potchefstroom : PU vir CHO. (M.A.-verhandeling.)

Van der Walt, P.D. 1984. T.T. Cloete: Die waarheid gelieg. Woord en Daad, Oktober.

Venter, L.S. 1984. Prosadebuut is 'n waardige bydrae. Die Volksblad, 29 Desember. 
